IRA-International Journal of Management \& Social Sciences

ISSN 2455-2267; Vol.07, Issue 02 (2017)

Pg. no. 302-308

Institute of Research Advances

http://research-advances.org/index.php/RAJMSS

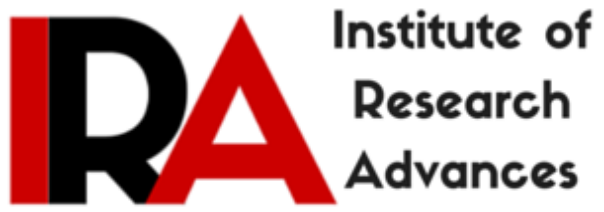

\title{
Skill Development for Youths: Recent Initiatives in Karnataka
}

\section{Dr. Shankar Chatterjee}

Former Prof \&Head (CPME)

NIRD \&PR, Hyderabad-500 030, Telangana, India.

Type of Review: Peer Reviewed.

DOI: http://dx.doi.org/10.21013/jmss.v7.n2.p21

\section{How to cite this paper:}

Chatterjee, S. (2017). Skill Development for Youths: Recent Initiatives in Karnataka. IRAInternational Journal of Management \& Social Sciences (ISSN 2455-2267), 7(2), 302-308. doi:http://dx.doi.org/10.21013/jmss.v7.n2.p21

(C) Institute of Research Advances

\section{(c) EY-NO}

This work is licensed under a Creative Commons Attribution-Non Commercial 4.0 International License subject to proper citation to the publication source of the work.

Disclaimer: The scholarly papers as reviewed and published by the Institute of Research Advances (IRA) are the views and opinions of their respective authors and are not the views or opinions of the IRA. The IRA disclaims of any harm or loss caused due to the published content to any party. 


\section{ABSTRACT}

Unemployment is a serious issue in India as well as in all the states as many youths are having educational qualifications but not skills as a sequel they are not employable. In view of this, the Government of India has set up Ministry of Skill Development And Entrepreneurship in recent years. The Ministry is responsible for co-ordination of all skill development efforts across the country, removal of disconnect between demand and supply of skilled manpower, building the vocational and technical training framework, skill up-gradation, building of new skills, and innovative thinking not only for existing jobs but also jobs that are to be created. Like other State Governments, the Government of Karnataka has taken initiative to set up the Skill Development, Entrepreneurship and Livelihood Department to address skilling issues in the State. The Department came into existence in September 2016 to embark on a formidable journey of skilling youth of the state and make them employable.

The goal of the skill development in Karnataka is to impart skills annually to 13.4 lakh workforce and new entrants who desire to achieve sustainable livelihood either through wage employment or selfemployment. Policy will focus primarily on young persons of 16 to 35 years of age for the period from 2016 to 2030. In this research paper few important initiatives are highlighted.

Key words: Karnataka, Skill Development, Unemployment and Youth.

Considering the huge number of population in India, (134.96crore as of May 15, 2017), (www.indiaonlinepages.com) working age group of population is also huge in number. Recently, the NITI Aayog came out with its Three-Year Action Agenda, which will be followed by a Seven-Year Strategy and a Fifteen-Year Vision. The 200-page Action Agenda (AA) is comprehensive, systematic and ambitious. It makes clear the need for rapid and sustained economic growth to get everyone out of poverty (https://in.news.yahoo.com). Further, the Action Agenda stresses on both moving resources into labour-intensive sectors as well as making individual sectors more efficient in every way possible inter alia with increasing the scale of production and improving technology. The Government of India has set up Ministry of Skill Development And Entrepreneurship in recent years. The Ministry is responsible for co-ordination of all skill development efforts across the country, removal of disconnect between demand and supply of skilled manpower, building the vocational and technical training framework, skill upgradation, building of new skills, and innovative thinking not only for existing jobs but also jobs that are to be created.

"The Ministry aims to Skill on a large Scale with speed and high standards in order to achieve its vision of a 'Skilled India'. It is aided in these initiatives by its functional arms - National Skill Development Agency (NSDA), National Skill Development Corporation (NSDC), National Skill Development Fund (NSDF) and 33 Sector Skill Councils (SSCs) as well as 187 training partners registered with NSDC. The Ministry also intends to work with the existing network of skill development centers, universities and other alliances in the field.

Further, collaborations with relevant Central Ministries, State governments, international organizations, industry and NGOs have been initiated for multi-level engagement and more impactful implementation of skill development efforts" ( http://www.skilldevelopment.gov.in/aboutus.html). Like other States, in Karnataka skill development has been given importance.

The recent Report (Koushalya Karnataka, May 2017) prepared by the Government of Karnataka reveals the fact that in Karnataka with a population of 6.11 crore has 55percent of the population in the working age group of 20 to 59 years which may be used in a favourable demographic advantage provided appropriate skills at the right time are imparted to them. Human resource mapping in the state portrays that nearly 54 percent of the youth comprise illiterate or those completed primary and middle education; 
29 percent finished secondary and higher secondary. The students completed diploma, graduation and above are around 17 percent. Of these a total of 11 lakh youths enter labour market every year in Karnataka. In addition, there are large numbers of drop outs who can be gainfully employed, otherwise these disgruntled youths may create law and order problem. It is pertinent to mention that many of the students after completion of degree are unemployable as they have degree but not employable skill. Such youths can be absorbed as primary teacher/police/ home guard etc., but as these are unproductive sector as sequel large number of youths cannot be provided with employment. To get a prima facie idea about the unemployable youths, albeit having qualification, few examples may be cited here to understand the reality. This case is from West Bengal where unemployment is a serious issue. Around 25 lakh youths appeared on $20^{\text {th }}$ May 2017 in a competitive written examination for 6,000 Group D posts of the West Bengal Government. It is believed that many of them have completed college education or higher level. The examinees included 5.5 lakh from neighboring states such as Bihar and Jharkhand (https://dailyworld.in/25-lakh-candidates-appear-in-bengal-group-d-exam).Unemployment is a serious issue in Jammu and Kashmir as few years back when the author visited in Kashmir valley many persons told the author in this regard. As per the recent news, In Jammu and Kashmir, around 1, 18,000 applications across the state appeared for the posts of 5,362 constables and 70,000 candidates applied for the posts of 680 sub-inspectors. There were female candidates also. Many of them were highly qualified indicating job market has been shrinking in proportionate to the number of youths entering in the market (http://indianexpress.com/article/cities/srinagar/jammu-and-kashmir-1-18-lakh-bid-for-5362-constableposts-in-state-4656007). According to the Times of India $7^{\text {th }}$ May 2017 Hyderabad edition, for recruitment of constable in Telangana, a total of 7379 police constables were selected out of 5.63 lakh candidates. And many aspirants were MBA, M. Tech, B. Tech, Post-graduate etc.

In case of Uttar Pradesh the unemployment situation is alarming. According to a newsletter, published by Nav Bharat Jagriti Kendra, Hazaribagh, Jharkhand (January-March 2016 issue), "In 2015 altogether 23 lakh youths applied for 368 posts of peon in the state secretariat of Uttar Pradesh. Among the applicants, 255 candidates with a Ph.D. degree and more than two lakh hold B.Tech, B.Sc., M.Com \& M.Sc. degrees. This episode reflects our mind set and dealing with the youths. It may be mentioned that 44.79 million Indian youths were unemployed in 2012 and the rate was higher among educated youths than their illiterate counterparts. One out of every three graduates is unemployed in India. In Jharkhand, about 42 percent households are with unemployed persons. The situation is alarming as unemployment not only has financial impact but also has many social impacts like increase in cases of theft, violence and other criminal activities". The case of UP reflects that for 368 posts that too for peon posts youths with Ph. D., Post-graduate and Graduate degree applied indicating there is urgent need for manpower planning with focus on skill development so that youths, according to their qualification, may be employed in dignified job. Simultaneously, population growth needs to be controlled. And for this many issues have to be looked into, following table provides an idea in this regard which with reference to some states are mentioned.

Table 1: Indicators on Literacy \&IMR in Some States of India

\begin{tabular}{|l|l|l|l|l|l|}
\hline S.No. & Indicator & $\begin{array}{l}\text { Arunachal } \\
\text { Pradesh }\end{array}$ & Assam & Manipur & Meghalaya \\
\hline a. & $\begin{array}{l}\text { Total Literacy (\%) Total } \\
2011\end{array}$ & 66.9 & 73.2 & 79.8 & 75.4 \\
\hline b. & $\begin{array}{l}\text { Female literacy Rate (\%)- } \\
2011\end{array}$ & 59.8 & 67.3 & 73.1 & 73.8 \\
\hline C & $\begin{array}{l}\text { Infant Mortality Rate_Rural } \\
\text { 2012 (per thousand } \\
\text { births) }\end{array}$ & 58 & --- & --- \\
\hline
\end{tabular}




\begin{tabular}{|l|l|l|l|l|l|}
\hline Sl.No. & Indicator & Mizoram & Nagaland & Sikkim & Tripura \\
\hline a. & Total Literacy (\%) 2011 & 91.6 & 80.1 & 82.2 & 87.6 \\
\hline b. & Female literacy Rate (\%)-2011 & 89.4 & 76.7 & 76.4 & 83.2 \\
\hline c. & $\begin{array}{l}\text { Infant Mortality Rate _Rural - } \\
2012\end{array}$ & --- & --- & --- & ---- \\
\hline
\end{tabular}

\begin{tabular}{|l|l|l|l|l|l|}
\hline Sl.No. & Indicator & Bihar & Jharkhand & Odisha & $\begin{array}{l}\text { West } \\
\text { Bengal }\end{array}$ \\
\hline a. & Total Literacy (\%) 2011 & 63.8 & 67.6 & 73.4 & 77.1 \\
\hline b. & Female literacy Rate (\%)-2011 & 53.3 & 56.2 & 64.4 & 71.1 \\
\hline C & $\begin{array}{l}\text { Infant Mortality Rate_Rural } \\
2012 \quad 4\end{array}$ & 44 & 39 & 55 & 33 \\
\hline
\end{tabular}

\begin{tabular}{|l|l|l|l|l|l|l|l|}
\hline S.No. & Indicator & Haryana & $\begin{array}{l}\text { Himachal } \\
\text { Pradesh }\end{array}$ & J \& K & Punjab & $\begin{array}{l}\text { Rajas- } \\
\text { than }\end{array}$ & $\begin{array}{l}\text { Uttara } \\
\text { khand }\end{array}$ \\
\hline a. & $\begin{array}{l}\text { Total Literacy } \\
(\%) \text { Total 2011 }\end{array}$ & 76.6 & 81.78 & 68.7 & 76.7 & 67.0 & 79.6 \\
\hline b. & $\begin{array}{l}\text { Female literacy } \\
\text { Rate (\%)-2011 }\end{array}$ & 66.7 & 76.6 & 58.0 & 71.3 & 52.6 & 70.7 \\
\hline C & $\begin{array}{l}\text { Infant Mortality } \\
\text { Rate_Rural - } \\
2012 \quad \text { ( per } \\
\text { thousand births) }\end{array}$ & & --- & --- & 30 & 54 & -- \\
\hline
\end{tabular}

\begin{tabular}{|l|l|l|l|}
\hline Sl.No. & Indicator & Gujarat & Maharashtra \\
\hline a. & Total Literacy (\%) Total 2011 & 79.3 & 82.9 \\
\hline b. & Female literacy Rate (\%) - 2011 & 70.7 & 75.4 \\
\hline C & $\begin{array}{l}\text { Infant Mortality Rate_Rural - 2012 ( per } \\
\text { thousand births) }\end{array}$ & 45 & 30 \\
\hline
\end{tabular}

\begin{tabular}{|l|l|l|l|l|l|}
\hline S.No. & Indicator & A.P. & $\begin{array}{l}\text { Karnatak } \\
\text { a }\end{array}$ & Kerala & $\begin{array}{l}\text { Tamil } \\
\text { Nadu }\end{array}$ \\
\hline a. & Total Literacy (\%) Total 2011 & 67.6 & 75.6 & 93.9 & 80.3 \\
\hline b. & Female literacy Rate (\%) - 2011 & 59.7 & 68.1 & 92.0 & 73.8 \\
\hline C & $\begin{array}{l}\text { Infant Mortality Rate_Rural - 2012 } \\
\text { (per thousand births) }\end{array}$ & 46 & 36 & 13 & 24 \\
\hline
\end{tabular}

Source: Compiled from NIRD, Hyderabad, 2007 \& Population Census 2011

Although table is self-explanatory, however few of the important points as observed from the table are:

Female literacy is an indicator of development as it is believed that educated mother means educated child. The data on female literacy rate reveal the fact that again in many India's northern belt spanning from Rajasthan to Bihar, same is low than South Indian states.

Same is the case of IMR, wide variations are observed across the states. 
Further while analyzing region wise development indicators of India, Saurabh Mukherjea and Ritika Mankar-Mukherjee, (Business Standard, 21/4/16) had pointed out that per-capita income in Northern belt of India spanning from Rajasthan to Bihar was \$1200 compared to \$2000 in the southern part of India. The authors were in the opinion that in the Hindi belt areas spanning from Rajasthan to Bihar, because of lack of skill, youths were not getting desired job. Agriculture albeit has been providing 60 percent employment to the youths but its pace of development is much low. The authors have also observed that 21 percent of India's population eke out their livelihood by earning less than $\$ 1.9$ per day and most of them hail from Hindi belt.

From the above discussion vis-à-vis practical examples, it evident that only through skill development the youths can be made employable. In this section the initiatives of Government of Karnataka for skill development are presented.

\section{Need for Skill Development: Initiatives in Karnataka}

The points of this section have been collected from the Report Koushalya Karnataka, published by Skill Development, Entrepreneurship and Livelihood Department, May 2017, Government of Karnataka.

The Skill Development, Entrepreneurship and Livelihood (SDEL) Department came into existence in September 2016 vide G.O. No. LD 164 SAS 2016, to embark on a formidable journey of skilling youths of the State and make them employable. The Department also envisages imparting training to the youths for self-employment or entrepreneurship development for sustained livelihood. It is evident from the statistics that in present scenario several short-term vocational trainings are imparted by various departments and government organizations, but they do not train to their full capacity. Although Karnataka has an impressive educational infrastructure, skill landscape portrays poor utilization of the existing skill training infrastructure with low intake(Table 2). Students pursuing formal education can benefit from hands-on training provided through apprenticeship, but present apprentice intake is pitifully low compared to the total capacity.

Table: 2 Short term vocational education/Informal VTP

\begin{tabular}{|l|l|l|l|l|}
\hline Sl.No. & Institutions & Intake capacity & Admitted & $\begin{array}{l}\text { Pass } \\
\text { employed }\end{array}$ \\
\hline 1. & Textiles & 19,523 & 19,523 & 19,523 \\
\hline 2. & Technical Education & 40,000 & 15,000 & 15,000 \\
\hline 3. & $\begin{array}{l}\text { Karnataka Vocational Training and Skill } \\
\text { Development Corporation }\end{array}$ & 25,000 & 16,000 & 16,000 \\
\hline 4. & DAY-NRLM & 17,500 & 2,322 & 2,322 \\
\hline 5. & NULM & 45,000 & 22,000 & 8,336 \\
\hline 6. & Women Development Corporation & 6,590 & 3,833 & 3,833 \\
\hline 7. & Construction Academy/ Nirmithi Kendra & 30,000 & 3,000 & 3,000 \\
\hline 8. & Leather & 564 & 564 & 564 \\
\hline 9. & Motor Vehicle Driving & 401 & 401 & 401 \\
\hline 10. & IT \& BT (ITCSDS) & 185975 & 84040 & 56040 \\
\hline & Total & $1,84,403$ & 83,000 & 55,000 \\
\hline
\end{tabular}

Source: Koushalya Karnataka, published by Skill Development, Entrepreneurship and Livelihood Department, May 2017

Although table is self-explanatory but one important point as observed from the table is that out of intake capacity of 1,84,403 altogether 83,000 youths were trained of which only 55,000 were placed for employment as they could successfully complete training. However, the goal of the skill development policy in Karnataka is to provide skills annually to 13.4 lakh existing workforce and new candidates who wish to earn descend income either through wage employment or through self-employment. 


\section{Goal of the Skill Development, Entrepreneurship and Livelihood (SDEL)}

As mentioned already the goal of the Skill Development, Entrepreneurship and Livelihood (SDEL) of Karnataka is to provide skills annually to 13.4 lakh workforce and new entrants who want to achieve sustainable livelihood. The policy will focus primarily on young persons (16 to 35 years).

\section{Target group projections for the period 2016 to 2030 are presented below}

* Around 75 lakh persons are in need of skills in 2016 -called as stock.

* About 113 lakh youths are fresh candidates during the period2017 to 2030 - called as flow

* Total number of youths to be trained during the period 2017 to 2030 is thus 188 lakhs - both as stock and flow.

* However, annual target of persons to be trained is 13.4 lakh during this period.

The Department recognizes that in order to make skilling accessible to all following vibrant steps need to be taken.

> Information and awareness programmes will be created and transmitted through newspapers, mass media, etc., to public in general and youth in particular. Modules and tools will be developed in Kannada.

$>$ Awareness programmes will focus on parents for their choice of carriers for their children as mostly the parents decide on their children's educational and vocational choice.

$>$ The curricula and training courses will be standardized in line with market demand and quality parameters.

It may be mentioned that the skill development may be taken up by the Government and Government is a major contributor to the funding on vocational education and skills. The international norm is to allocate $6 \%$ of GDP on general education, and $1 \%$ on vocational education. In Karnataka, the State Government allocates $0.5 \%$ of its Gross State Domestic Product (GSDP at current prices) on vocational education and training amounting to Rs. 3600 crores per year.

After analysis of labour force participation, occupational distribution, participation in the formal and informal sectors, general education and skill level of youths and social groups following suggestions have been made by the Karnataka State Skill Policy:

- Skill provision is urgently needed to promote employment among youth and bring them in to the labour force.

- Policy needs to be gender sensitive and priority to women especially to young home makers in skill provision and enable them to take up gainful employment. In addition, vocational training institutions should be sensitive to the needs of women candidates.

- Imparting appropriate skills to the physically challenged so that they are empowered to takeup employment.

- Focus on workers in the unorganized sector, especially to SC and ST and women in order to address social and gender disparities in the access to employable skills so that they can be suitably employed.

- Vocational skills to be introduced from the eighth standard ensuring some amount of skilling for employment for dropouts.

- Bring changes in the curricula of higher secondary education in favour of vocational skills to improve employment prospects in the formal sector

\section{Conclusion}


Karnataka with a population of 6.11 crore (as per 2011 census) has $55 \%$ of the population in the working age group of 20 to 59 years. This can be converted into a favourable demographic advantage provided appropriate skills at the right time are imparted to them. Human resource mapping in the State depicts that nearly $54 \%$ of the youths were illiterate or completed primary and middle education, $29 \%$ completed secondary and higher secondary and $17 \%$ completed diploma, graduation and above. Of these, a total of 11 lakh youths enter labour market every year. In addition, there is large number out of school or drop outs who find it difficult to be gainfully employed, which is a matter of serious concern. Even many of the students passing out from degree levels are unemployable. It is only through skilling, re-skilling and up-skilling that they all can be made employable. So the initiative of Karnataka Government through its Skill Development, Entrepreneurship and Livelihood (SDEL) Department which has been newly created is praise worthy step. Its success can be understood only after the impact evaluation study conducted 4/5 years later.

\section{References}

1. http://www.indiaonlinepages.com/population/india-current-population.html dt $16^{\text {th }}$ May 2017;

2. https://in.news.yahoo.com/why-niti-aayog-job-creation-142855842.html, dt16 ${ }^{\text {th }}$ May, 2017;

3. http://indianexpress.com/article/cities/srinagar/jammu-and-kashmir-1-18-lakh-bid-for-5362constable-posts-in-state-4656007.

4. http://www.skilldevelopment.gov.in/aboutus.html, dt $29^{\text {th }}$ May 2017

5. Nav Bharat Jagriti Kendra, Hazaribagh, Jharkhand, Newsletter January-March 2016. 